\title{
2. Pāli Suttas Printed in Ceylon.
}

Str,--In view of the value of the Pâli Sutta-literature, of which a fresh and interesting specimen appeared under Mr. Chalmers's editorship in the last number of the Journal, it may be of value to enumerate the Suttas that have been recently (i.e. since the publication of my Catalogue of Sanskrit and Pāli Books) printed in Ceylon :

Anguttara-nikāya. Complete edition of text commenced.

Colombo, 1893.

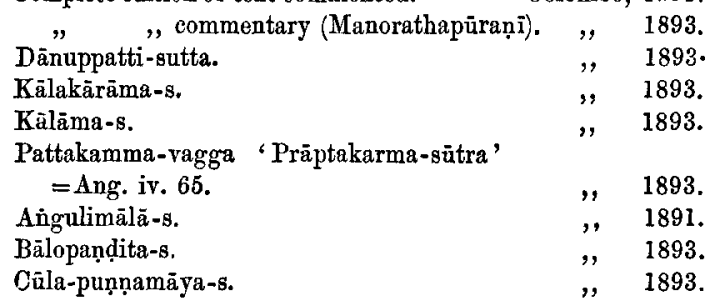

Also a 'Vyāghra-padya '-sūtra (differing from Añguttara iv. 194), and an Āṣivísopama-sutta, not yet identified.

All the above separate Suttas have Sinhalese interpretations (padagata sanna).

It is most unfortunate that the editors (Dr. Trenckner and Dr. Morris) of two of the chief collections of Suttas, the Majjhima and Anguttara, should have been removed by death with their work unfinished. It is to be hoped that these important texts will not be left long incomplete.

C. Bendall.

3. The New Burmese Dictionary.

Dear Prof. Rhys Davids,-May I be allowed a few words on Stevenson's most useful new Burmese Dictionary.

We do not call the new English Dictionaries revised Johnsons, and it cannot be conceded that the American Baptist Missionaries have any claim to copyright in Judson. This is really a new work. The old dictionary consisted of 786 pages; the present consists of 1188 pages 